\title{
CRP-nivå som risikomarkør for hjerte- og karsykdom?
}

\author{
I Norge har vi en sterk tradisjon for å bruke serum-kolesterolnivå, blodtrykk og røyking \\ for å vurdere den individuelle risikoen for hjerte- og karsykdommer. Inflammasjon er en \\ viktig mekanisme i ateroskleroseprosessen, og C-reaktivt protein er knyttet direkte til \\ inflammasjonen. Men proteinet er uspesifikt, og foreløpig foreligger det ikke tilstrekkelig \\ dokumentasjon på at det bør måles rutinemessig hos ellers friske mennesker.
}

\section{Dag S. Thelle}

d.s.thelle@medisin.uio.no

Avdeling for statistikk

Universitetet i Oslo

Postboks 1122 Blindern

0317 Oslo

\section{Egil Arnesen †}

Institutt for samfunnsmedisin

Universitetet i Tromsø

I 1966 brukte Jeremiah Stamler (f. 1919) begrepet «koronare risikofaktorer» om alle elementer som var assosiert med koronar hjertesykdom, uansett om de kunne kalles årsaksfaktorer eller bare var indikatorer for $ø$ kt risiko (1). Noe av hensikten med denne løse avgrensningen var at man ikke kunne ta standpunkt til om det virkelig dreide seg om årsaksfaktorer, men de kunne anvendes til å identifisere individer med forhøyet risiko for klinisk koronarsykdom. Dermed omfatter definisjonen både ytre årsaker, som livsstil og miljøfaktorer, mellomliggende biologiske variabler som befinner seg i årsakskjeden, som LDL-kolesterolnivå, og subkliniske patologiske effekter, som asymptomatiske aterosklerotiske forandringer i halskarene.

Interessen for koronarsykdommens epidemiologi og risikofaktorer var en direkte konsekvens av utviklingen i USA fra 1920 og 40 år fremover. I denne perioden økte dødeligheten av hjerte- og karsykdommer fire ganger, samtidig med at en rekke andre dødsårsaker ble mindre fremtredende.

Tilsvarende forandringer i dødelighets- og sykelighetsmønsteret så man også i Norge. Ved Oslo-sykehusene Ullevål, Aker og Lovisenberg ble det registrert en betydelig økning i innleggelser i perioden 1935-49 (avbrutt av en nedgang i krigsårene 1941-45). Deretter kom en ny økning. I årene 1947-60 var det en femdobling i frekvensen av slike sykdommer hos menn $i$ alderen 40-59 år, og økningen hos kvinner i alderen 60-69 år tilsvarte den man så hos menn i alderen 50-59 år $(2,3)$. De samme tendensene så man igjen i dødelighetsregistreringen fra Statistisk sentralbyrå. Etter krigen kom det en eksplosiv økning også i dødeligheten av hjerteinfarkt, med en avflatning av dødelighetskurven fra slutten av 1960-årene. Deretter var det en betydelig nedgang fra begynnelsen av 1970-årene, en nedgang som har vart helt frem til nå.

I 1963 ble regjeringen forelagt en «betenkning om forholdet mellom fett og hjerte-kar-sykdommer», utarbeidet av en komité som skulle utrede forholdet mellom fettinnholdet i kosten og hjerte- og karsykdommene. Komiteen understreket betydningen av alder, blodtrykk, sigarettkonsum og stress, men la hovedvekten på blodets kolesterolinnhold og sammenhengen med fettinntaket. Dette ble en del av grunnlaget for norsk ernæringspolitikk og en grunnstein i det forebyggende arbeidet mot hjerte- og karsykdommer.

Komiteens innstilling må ses i lys av Harbitz \& Müllers påvisning av sammenhengen mellom familiært betinget forhøyet blodkolesterolnivå, fettknuter i underhuden (xantomatose) og angina pectoris (4). Dette, sammen med Knut Westlund (1923-2007) \& Ragnar Nicolaysens (1902-86) arbeider, brakte kolesterolnivået for alvor inn i diskusjonen om årsaksmekanismene ved koronarsykdommen i Norge (5). Westlund \& Nicolaysen fant at insidensen av både angina pectoris og hjerteinfarkt økte sterkt med økende serum-kolesterolnivå. Denne sammenhengen kunne de bekrefte ved en tiårsoppfølging, der risikoen for angina eller hjerteinfarkt samlet økte fra $2,3 \%$ til $37,4 \%$ når serum-kolesterolnivået økte fra $4,4 \mathrm{mmol} / \mathrm{l}$ til $8,9 \mathrm{mmol} / \mathrm{l}$ (omregnet til dagens benevning) (6).

Serum-kolesterolnivået hadde ikke så stor betydning for cerebrovaskulære hendelser, her betydde blodtrykket mer. Høyt blodtrykk, både systolisk og diastolisk, var også assosiert med risikoen for hjerteinfarkt - jo høyere blodtrykk, desto høyere risiko - men gradienten var ikke så uttalt som for serum-kolesterol. Økende kroppsvekt var assosiert med økende risiko for type 2-diabetes. På grunnlag av totalt serum-kolesterolnivå, blodtrykk, røykevaner og kjønn utarbeidet Westlund en risikoskår som senere er blitt brukt i norske materialer. Dette arbeidet er videreført og bekrefter totalkolesterolnivåets betydning som risikofaktor (7) og at en multifaktoriell risikoskår er det som best predikerer fremtidig sykdom.

\section{Gir nye risikofaktorer mer enn de «gamle»?}

I dag oppfattes aterosklerose som en inflammatorisk prosess og ikke bare som en passiv avleiring av blodlipider. Det var verken Ross eller Mata som først foreslo dette $(8,9)$, allerede Rudolf Virchow (1821-1902) hadde postulert liknende teorier basert på sine undersøkelser av det han kalte endarteritis nodosa (10).

En av markørene for inflammatoriske prosesser, C-reaktivt protein (CRP), er blitt foreslått som en selvstendig og uavhengig risikofaktor for hjerte- og karsykdom. Munk \& Larsen anbefaler i en nyere artikkel at man inkluderer denne faktorens rolle som risikomarkør for slike sykdommer (11). Vi mener at det fortsatt er usikkert i hvilken grad det uspesifikke Creaktive proteinet er en kausal faktor som skal brukes som indikasjon for å behandle f.eks. individer med «normale» blodlipider med statiner. Hvor uspesifikt C-reaktivt protein egentlig er, ble vist av Lise Lund Håheim og medarbeidere nylig (12). De viste i en tverrsnittsstudie med 5323 menn i alderen 48-77 år at CRP-nivået var forhøyet ikke bare hos pasienter med gjennomgått hjerteinfarkt, men også hos dem som hadde astma, diabetes, kronisk obstruktiv lungesykdom, osteoporose, fibromyalgi og andre kroniske smerter. Dermed er brukbarheten av CRP-nivå som screeningverktøy og risikoprediktor betydelig redusert. 


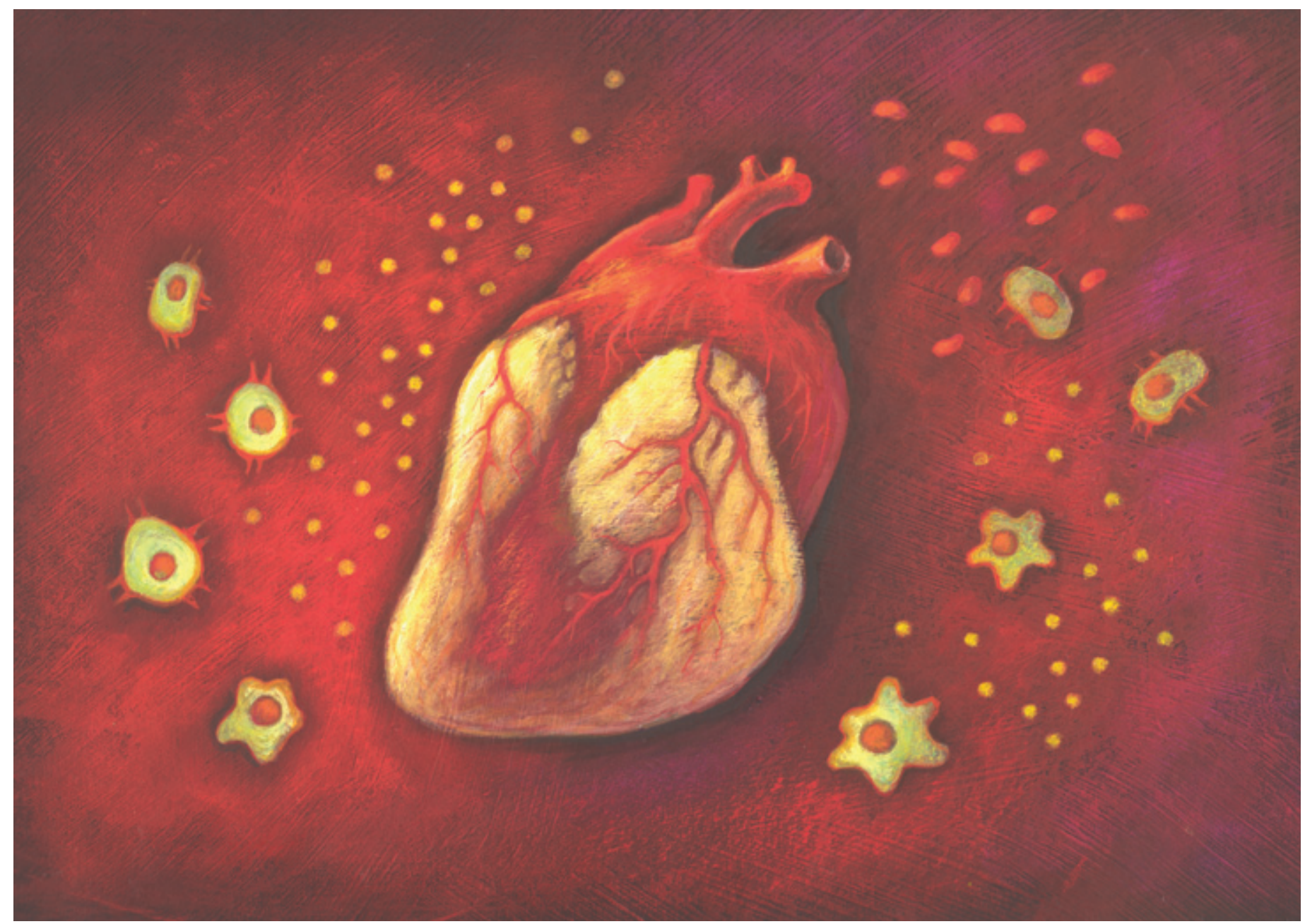

Illustrasjon Stein Løken

\section{JUPITER-studien}

Men viktigere er kanskje hvordan man skal tolke resultatene fra JUPITER-studien, som ble publisert i november 2008 (13). I den nettbaserte utgaven av denne artikkelen hadde redaksjonen i New England Journal of Medicine lagt ut muligheten til å si om man mente mennesker med forhøyet CRPnivå skulle behandles med statiner eller ei. Åpenbart var redaksjonen også i tvil. Resultatene, i det minste de som er offentliggjort, fortjener en nøyere omtale. Så langt er dette det eneste kontrollerte forsøket der CRPnivå har vært brukt som indikasjon for intervensjon med hjerte- og karsykdommer som endepunkt.

JUPITER-studien er en stor randomisert multisenterundersøkelse som omfattet 1315 studiesteder i 26 land og totalt 17802 individer. Bortsett fra at de skulle ha forhøyet CRP-nivå ( $\geq 2 \mathrm{mg} / \mathrm{l})$ var de friske. LDL-kolesterolnivået skulle ikke være over $3,4 \mathrm{mmol} / \mathrm{l}$. Behandlingen var $20 \mathrm{mg}$ rosuvastatin eller placebo, og endepunktene var «major cardiovascular events». Mange ventet på resultatene av JUPITER-studien, og allerede i mars 2008 annonserte man at forsøket skulle avbrytes fordi man hadde sett en utvetydig reduksjon i kardiovaskulær dødelighet i statinbehandlingsgruppen.

Rapporten som kom et halvt år senere, viste ikke noen slik reduksjon.

Det er to prinsipielle spørsmål man skal stille seg når man vurderer resultatene $\mathrm{av}$ et behandlingsforsøk:

- Er studien gjennomført uten noen systematiske feil når det gjelder tilordning av behandling/placebo og registrering av endepunkter?

- Kan resultatene generaliseres til den allmenne populasjonen?

Det første spørsmålet er gjerne basert på en vurdering av hvordan studien ble gjennomført i forhold til hva man opprinnelig planla i forsøksprotokollen. Vi har ingen grunn til å tvile på at studien ble gjennomført $\mathrm{i}$ henhold til protokollen (14) og antar derfor at svaret på dette spørsmålet er ja. Når det gjelder det andre spørsmålet, er saken ganske annerledes.

Studien ble avsluttet tidligere enn planlagt, da forfatterne mente at de ikke kunne la placebogruppen fortsette ubehandlet fordi forskjellen i dødelighet var for stor. Det totale antall fatale infarkter var ni i rosuvastatingruppen og seks i placebogruppen. Legger vi til tallene for hjerneslag, var det tre i rosuvastatingruppen og seks i placebogruppen. Det gir 12 dødsfall av hjerteinfarkt og hjerneslag til sammen $\mathrm{i}$ hver gruppe - med andre ord ingen forskjell. Den største effekten av behandlingen var det på de ikke-fatale kardiovaskulære hendelsene. Behandlingen har ingen betydning for hjerte- og kardødeligheten i de to gruppene, derimot er det stor forskjell i totaldødelighet mellom de aktivt behandlede og placebogruppen. Dessverre er det umulig for oss å vurdere betydningen av denne forskjellen, siden forfatterne ikke forteller oss hva disse dødsfallene «handler om». Det eneste man kan regne seg til er at det heller ikke er forskjeller i annen hjerteog kardød mellom gruppene - 19 i rosuvastatingruppen og 23 i placebogruppen.

Populasjonen som ble inkludert i JUPITER-studien er åpenbart en lavrisikogruppe som skiller seg sterkt fra en norsk befolkning, noe som også reflekteres ved at det av 68 infarktpasienter i placebogruppen bare døde seks i løpet av oppfølgingstiden, langt færre enn det man kunne forvente. I tillegg var forholdet mellom hjerneslag og hjerteinfarkt i begge gruppene nær $1: 1$. I de fleste industrialiserte land er det 3-4 hjerteinfarkter per hjerneslag i den aldersgruppen som inngår i JUPITER-studien. 


\section{Konklusjon}

JUPITER-studien er en viktig undersøkelse der man forsøker å nærme seg stort folkehelseproblem ut fra en nyere og åpenbart relevant mekanistisk tankegang. Samtidig gir den resultater som antyder at den undersøkte populasjonen avviker meget fra den allmenne befolkningen, dermed blir overføringsverdien tilsvarende redusert. Før vi inkluderer CRP-nivå i vårt risikofaktorpanel og eventuelt starter behandling med statiner på indikasjonen høyt CRP-nivå, må vi ha flere oppfølgingsstudier der CRP-nivå er inkludert sammen med andre risikofaktorer og behandlingsforsøk der statiner er gitt til individer med ulike CRP-nivåer. I en norsk virkelighet er fremdeles totalt serumkolesterolnivå, røyking og blodtrykk det som beskriver risikosituasjonen best. En reduksjon av disse faktorene er det som vil gi størst folkehelsegevinst.

Oppgitte interessekonflikter: Ingen

\section{Litteratur}

1. Stamler J, Berkson DM, Lindberg HA et al. Coronary risk factors: their impact, and their therapy in the prevention of coronary heart disease. Med Clin North Am 1966: 50: 229-54.

2. Westlund K. Hjerteinfarkt blant middelaldrende menn i Oslo 1956-57. Nord Med 1961; 65: 290-6.

3. Westlund K, Hougen A. Myocardial infarction among middle-aged Oslo males 1956-57. J Oslo Cy Hospital 1963; 11: 21-83.

4. Müller C. Angina pectoris in hereditary xanthomatosis. Arch Intern Med 1939; 64: 675-700.

5. Westlund K, Nicolaysen R. Serum cholesterol and risk of mortality and morbidity. Scand J Clin Lab Invest 1966; 18: 1-19.

6. Westlund K, Nicolaysen R. Ten-year mortality and morbidity related to serum cholesterol. A followup of 3.751 men aged $40-49$. Scand J Clin Lab Invest Suppl 1972: 127: 1-24.

7. Lindman AS, Veierød MB, Pedersen Jl et al. The ability of the SCORE high-risk model to predict 10 -year cardiovascular disease mortality in Norway. Eur J Cardiovasc Prev Rehabil 2007; 14: 501-07.

8. Ross R. Atherosclerosis is an inflammatory disease. Am Heart J 1999; 138: S419-20.

9. Mata P, Alonso R, Lopez-Farre A et al.Effect of dietary fat saturation on LDL oxidation and monocyte adhesion to human endothelial cells in vitro. Arterioscler Thromb Vasc Biol 1996; 16: 1347-55.

10. Buja LM, Willerson JT. Role of inflammation in coronary plaque disruption. Circulation 1994; 89: 503-5.

11. Munk PS, Larsen Al. Inflammasjon og C-reaktivt protein ved hjerte- og karsykdom. Tidsskr Nor Legeforen 2009; 129: $1221-4$

12. Håheim LL, Nafstad P, Olsen I et al. C-reactive protein variations for different chronic somatic disorders. Scandinavian Journal of Public Health 2009; 37: 640-6.

13. Ridker PM. Rosuvastatin in the primary prevention of cardiovascular disease among patients with low levels of low-density lipoprotein cholesterol and elevated high-sensitivity C-reactive protein: rationale and design of the JUPITER trial. Circulation 2003; 108: 2292-97.

14. Ridker PM, Danielson E, Fonseca FA et al. Rosuvastatin to prevent vascular events in men and women with elevated C-reactive protein. N Engl J Med 2008; 359: 2195-207. 